\title{
Vellykket satsing på kognitiv miljøterapi
}

Kognitiv terapi er en anerkjent metode innen psykiatri.

Sykepleietjenesten ved psykiatrisk sengepost på Lovisenber g Diakonale Sykehus bruker nå teknikker fra metoden til å planlegge og gjennomføre meningsbærende samtaler med pasientene.

\section{Forfattere}

\section{Geir Tarje Bruaset}

ledende spesialsykepleier i psykiatrisk sykepleie Lovisenberg Diakonale Sykehus

\section{Kjersti Sundbye}

enhetsleder, psykiatrisk klinikk

Lovisenberg Diakonale Sykehus

\section{Carina Midgaard}

Ledende spesialsykepleier i psykiatrisk sykepleie Lovisenberg psykiatriske klinikk

\section{Nøkkelord}

kognitiv terapi Miljøterapi Behandling Metode psykiatri

Sykepleien 2017 105(64279)(e-64279)

DOI: https://doi.org/10.4220/Sykepleiens.2017.64279

\section{HOVEDBUDSKAP}

Kognitiv terapi er anbefalt som behandlingsmetode i nasjonale retningslinjer for utredning, behandling og oppfølging av pasienter med psykoselidelser. Grunnlaget for modellen bygger på et positivt og ressursorientert menneskesyn, der pasienten skal være en likeverdig part i behandlingen. Hvordan kan man integrere behandlingsformen til pasienter ved psykiatrisk sengepost? Artikkelen viser et vellykket implementeringsprosjekt, der de ansatte ved sykepleietjenesten vokste på å ta ansvar. 


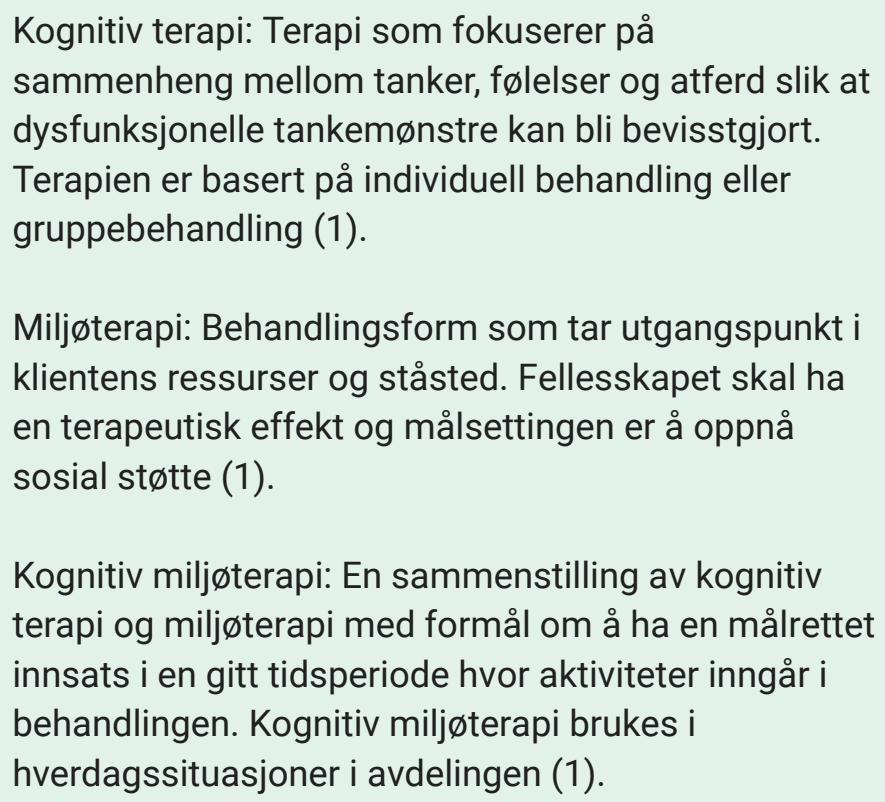

Kognitiv terapi er en anerkjent og populær behandlingsform, både for somatiske og psykiatriske lidelser, og anvendes i stadig større grad (2). Det er en veldokumentert behandlingsform, og behandlingen er blant annet anbefalt i nasjonale veiledere for psykiske lidelser (3). Kognitiv terapi ble utviklet av den amerikanske psykiateren Aaron Beck på 1960-tallet. Han utviklet en strukturert kortvarig «her og nå»orientert psykoterapi, opprinnelig rettet mot behandling av depresjon. I tillegg egner behandlingsformen seg til modifisering av dysfunksjonelle tankemønstre og atferd (4).

Et menneske med en psykisk lidelse kan ha en mental aktivitet bestående av strømmer med negative tanker og forestillingsbilder - av gårsdagen, dagen i dag eller tanker om fremtiden. Disse tankene kan være basert på høyst reelle hendelser og virker svært overbevisende for pasienten. Men de kan også være overdrevne eller direkte feilaktige (2). Et viktig mål i kognitiv terapi, er å hjelpe pasienten å identifisere negative tankemønstre. 
Målet i terapien er å gi innsikt i og forståelse av sammenhengen mellom negative tanker, ubehagelige følelser og uhensiktsmessig atferd. Terapien baserer seg på gjensidig respekt, en felles målsetting, konkrete åpne spørsmål og jevne tilbakemeldinger (2). Terapimetoden har vist seg å ha god effekt på reduksjon av ubehag knyttet til hørselshallusinasjoner (3). Den kan også bidra til å redusere negative symptomer, depresjon og sosial angst (4). Kognitiv terapi retter seg mot problemløsning både ved psykiske og somatiske plager, samt livsstilsendring ved alvorlig somatisk sykdom.

\section{Bakgrunn}

Kognitiv terapi er et satsingsområde for psykiatrisk klinikk ved Lovisenberg Diakonale Sykehus og er nedtegnet i handlingsplanen for 2015. Klinikken består av sju poster, og prosjektet ble utført på en av klinikkens lukkete, intensive sengeposter. Posten har som mål å integrere kognitiv terapi som behandlingsverktøy i sykepleietjenesten. Implementeringsprosjektet er godkjent av avdelingsledelsen, samt godt forankret i og initiert av sykepleieledelsen i posten, som består av avdelingssykepleier Kjersti Sundbye, og ledende spesialsykepleiere Carina Midgaard og Geir Tarje Bruaset.

\section{三 «Modellen har hjulpet sykepleieren til å fremme sin rolle som behandler.»}


Legene og psykologene ved posten er også opptatt av pasientenes tilbakemeldinger på opplevd nytte og verdi. Flere av personalet har tatt videreutdanning og intensivkurs i kognitiv terapi, og det har vært gjentatte internundervisninger om temaet. Personalet som har tatt denne videreutdanningen, opplever modellen som et nyttig verktøy i møte med pasienten. Modellen har hjulpet sykepleieren til å fremme sin rolle som behandler, ved å planlegge og gjennomføre meningsbærende samtaler med aktuelle temaer under pasientens innleggelse.

I forkant av implementeringsprosjektet, ble det nedfelt en ressursgruppe i kognitiv terapi ved den aktuelle sengeposten. Personalet som så langt ikke har fått systematisk opplæring i kognitiv terapi, viste interesse for behandlingsformen og ønsket opplæring.

I forkant av prosjektet ble det søkt om, og innvilget økonomisk støtte fra Lovisenberg Diakonale Høgskole. Studenter fra Høgskolen, som hadde sin praksis ved klinikken under prosjektperioden, ble inkludert i prosjektet i form av undervisning om grunnteknikker ved den kognitive modellen.

\section{Implementering}

Det finnes ingen allmenn implementeringsstrategi når man skal innføre kunnskapsbasert forskning i klinisk praksis. Det er en klar fordel at endringen skal være klinisk orientert, slik at sykepleietjenesten kan se nytten av forskning i praksis (6). Oppsummert forskning viser at passiv distribusjon av kunnskap eller didaktisk undervisning har minimal effekt på praksis og dermed ikke er nok for å endre praksis (7).

En viktig del av den pågående implementeringen har derfor vært et kontinuerlig fokus med overlappende aktiviteter, herunder workshops og en blandet aktiv og delaktig undervisningsform. Implementeringsprosjektet legger dermed opptil både undervisning og praktisk gjennomføring. 
Problemstilling for prosjektet har vært: «Hvordan

lykkes med opplæring og implementering av kognitiv miljøterapi for sykepleietjenesten ved posten og samtidig inkludere studenter i utviklingen?».

\section{Målsetting}

Kognitiv miljøterapi er et integrert behandlingsverktøy i sykepleietjenesten på posten. Det overordnete målet var å videreutvikle postens psykoedukasjonsgruppe i kognitiv terapi fra å omfatte angst- og depresjonsproblematikk, til også å inkludere psykoseproblematikk.

Målgruppen var sykepleietjenesten på posten - som består av sykepleiere, vernepleiere, hjelpepleiere, miljøterapeuter og studenter. Noen har videreutdanning i psykiatri og kognitiv terapi. I tillegg gjaldt det studenter som har sin praksisperiode i psykiatri på den aktuelle sengeposten.

Mål for studenter og sykepleietjenesten:

- Forstå grunnmodellen i kognitiv terapi

- Kjenne til og utføre kartleggingsverktøy i kognitiv terapi som viser sammenhengen mellom en tenkt situasjon, tanker som oppstår, og følelser knyttet til tankene

- Undervise pasienter og bruke kartleggingsverktøy i kognitiv terapi

- Undervise studenter i kognitiv terapi

- Styrke strukturen i pasientsamtaler ved hjelp av modellen i kognitiv terapi.

\section{Forløp og gjennomføring}


I prosjektet arrangerte avdelingen workshops og aktiv veiledning for å implementere kognitiv miljøterapi som behandlingsmetode for pasienter på psykiatrisk sengepost i perioden juni 2015-juni 2016. Det ble satt av 15 måneder til gjennomføring av prosjektet. I løpet av implementeringsperioden ble det holdt workshops og fagmøter i kognitiv terapi for ansatte i posten og for sykepleierstudenter knyttet til klinikken. Prosjektledere har gitt ansvaret til den delen av sykepleietjenesten som har hatt kjennskap til den kognitive modellen fra tidligere. Gradvis har det øvrige personale fått mer og mer ansvar for å ta del i undervisning av både pasienter og studenter.

\section{Etikk og juss}

Sykepleietjenesten er informert om prosjektet. All pasientdeltakelse i undervisningsgrupper er basert på frivillighet. Deltakere får informasjon om moralsk taushetsplikt i gruppen. I forkant av prosjektet ble det søkt og innvilget økonomisk støtte fra Lovisenberg Diakonale Høgskole.

\section{Spørreundersøkelse}

Det ble utført en anonym spørreundersøkelse - en «questback» - til alle ansatte ved posten i større stillingsprosenter før og etter at prosjektet var avsluttet.

Fordi kognitiv terapi har fått oppmerksomhet på klinikknivå, valgte prosjektledere å inkludere alle postens tverrfaglige ansatte, altså både ansatte som har og ikke har fokus på behandlingssamtaler med pasient. Resultatet omfatter da flere enn selve målgruppen.

Måloppnåelse:

- Forståelse av grunnmodellen i kognitiv terapi: De fleste av respondentene svarer at de forstår grunnmodellen i kognitiv terapi ved prosjektets avslutning.

- Undervisning av pasienten i grunnmodellen i kognitiv terapi: Før prosjektets start oppga 30 prosent av 
respondentene at de hadde brukt kognitiv terapi $\mathrm{i}$ planlagte samtaler. Ved prosjektets avslutning oppga 60 prosent at de hadde brukt kognitiv terapi $\mathrm{i}$ planlagte samtaler.

- Bruk av kognitiv terapi i «gylne øyeblikk»: 94 prosent av respondentene sier at de bruker teknikker $\mathrm{i}$ kognitiv terapi i spontane samtaler med pasienter. Før prosjektets oppstart oppga cirka 30 prosent at de brukte kognitiv terapi i spontane samtaler.

- Trygghet i bruk av den kognitive modellen: 69 prosent av de spurte opplevde å være lite trygg på bruk av den kognitive modellen ved oppstart. Ved prosjektets slutt svarer 37 prosent at de kjenner seg lite trygg.

Studentene har, sammen med sin veileder, fått tilbud om undervisning i kognitiv terapi. Undervisningen var en del av implementeringsstrategien, og ble holdt av postens personale som har gått intensivkurs i kognitiv terapi. Det viktigste har vært forståelse av grunnmodellen i kognitiv terapi og opplæring i bruk av kartleggingsverktøy.

Det er ikke gjennomført noen formell undersøkelse av studentenes opplevelse av ferdighetsnivå innen kognitiv terapi. Imidlertid har flere av studentene gitt muntlig tilbakemelding på undervisningen de har fått, og deres innspill har påvirket hvordan neste undervisningsbolk har blitt lagt opp. Således har studentene vært inkludert i prosjektet, både som passive og aktive deltakere.

Figur 1 under viser resultat av «questback» ved oppstart av implementeringsprosjektet, og ved prosjektets avslutning. 
Antatt effekt av prosjektet

Forstảelse av grunnmodellen i kognitiv terapi

Undervisning i grunnmodellen i kognitiv terapi

Bruk av kognitiv terapi i "gylne øyeblikk"

Trygghet $\mathrm{i}$ bruk av modellen

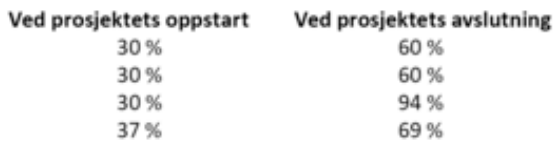

$37 \%-69 \%$

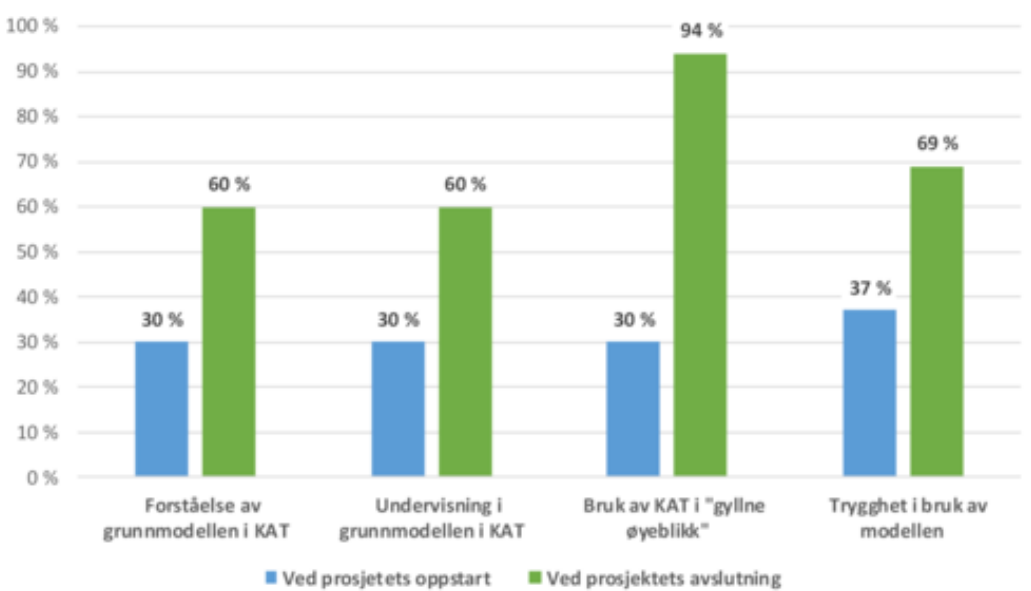

\section{Konklusjon}

Vårt hovedmål ved prosjektoppstart var at kognitiv miljøterapi skulle være et integrert behandlingsverktøy i sykepleietjenesten ved posten. Ut ifra svarene vi har fått i spørreundersøkelsen, later det til at personalet både har bedre kjennskap til og har en større tro på egne ferdigheter med kognitiv terapi og bruker teknikker fra modellen i planlagte, strukturerte pasientsamtaler.

\section{«Pasienter har gitt uttrykk for at tiltaket har hjulpet dem i egen tankegang, følelser og handlinger i konkrete hverdagssituasjoner.»}


Ett år etter prosjektimplementering, har de fleste i sykepleietjenesten holdt psykoedukasjonsgrupper for pasienter i kognitiv terapi. Pasienter har gitt uttrykk for at tiltaket har hjulpet dem i egen tankegang, følelser og handlinger i konkrete hverdagssituasjoner. Evaluering av personalets erfaringer gjennomført før og etter implementeringsperioden, viser en økt faglig forståelse og trygghet i bruk av modellen.

Videre arbeid med å se på allerede igangsatte tiltak blir viktig i tiden fremover, samt systematisk opplæring av nyansatte. Erfaring fra implementering av ny praksis viser at det tar tid å få til endring. Det er derfor viktig å opprettholde fokus på implementering av kognitiv miljøterapi.

Personalet har fått være med på en implementeringsprosess og utvikle seg faglig i sin kliniske hverdag. Det gis tilbakemelding om at ledelsen legger til rette for å implementere kognitiv miljøterapi, samt gir plass for at sykepleietjenesten skal lære seg modellen og å utvikle seg faglig. Respondentene opplever også at kognitiv terapi integreres i behandlingsteamet og behandlingsplanene til pasienten. Avdelingssykepleier har vært opptatt av at personalet skal drifte og være med på å utvikle undervisningsgruppe om temaet. Sykepleietjenesten har gitt tilbakemelding om at de kjenner på egen utvikling og har vokst på å få ansvar.

Postens leger og psykologer har også validert og støttet implementeringen av kognitiv miljøterapi. På et tverrfaglig seminar for posten uttalte en av psykiaterne følgende: «Det kjennes godt for meg som psykiater å følge denne utviklingen. Det er fint at sykepleietjenesten er med på å ta ansvar for noen av disse til tider utfordrende samtalene, og det avlaster mye av arbeidet mitt.» 
En spennende videreføring av prosjektet ville vært å kartlegge nytteverdi av den kognitive modellen hos pasienter som har blitt tilbudt kognitiv terapi. Flere av pasientene som har fått kjennskap til modellen, har imidlertid opplevd den så hensiktsmessig i eget liv, at behandlingen og igangsatte tiltak har blitt videreført i poliklinisk behandling.

\section{Referanse}

1. Solbjørg, M, Kleiven, H.H. Kognitiv miljøterapi forskningsbasert kunnskapssammenstilling. Nasjonalt kompetansesenter for psykisk helsearbeid. Tilgjengelig fra:

https://samforsk.no/Publikasjoner/Kognitiv\%20milj\%C3\%B8terapi\%20WEB.pdf (nedlastet 22.11.17)

2. Berge T, Repål P. Kort om kognitiv terapi. I: Berge

T, Repål A. (red). Håndbok i kognitiv terapi, Oslo:Gyldendal akademisk, 2014

3. Helsedirektoratet. Nasjonal faglig retningslinje for utredning, behandling og oppfølging av personer med psykoselidelser. Oslo:2013. Tilgjengelig fra:

https://helsedirektoratet.no/Lists/Publikasjoner/Attachments/326/Nasjona... (nedlastet: 28.11.2017).

4. Beck JS. Cognitive behavior therapy Basics and beyond Second edition. New York: The Guilford Press, 2011

5. Gjermundsen, K. Implementering som virker? Opplæring i kognitiv atferdsterapi ved alvorlige psykiske lidelser ved Lovisenberg Sykehus. 2014. Tilgjengelig fra: http://www.tipskompetansesenter.no/files/NyhetsTIPS/NyhetsTIPS022014-w... (nedlastet: 02.11.2017).

6. Sandvik G.K, Stokke, K, Nordtvedt MW. Hvilke strategier er effektive ved implementering av kunnskapsbasert praksis i sykehus? Sykepleien Forskning 20116 (2) s. 160-67 
7. Flottorp S, Aakhus E. Implementeringsforskning:

vitenskap for forbedring av praksis. Norsk

Epidemiologi,2013;23(2):187-96. Tilgjengelig fra

https://www.ntnu.no/ojs/index.php/norepid/article/viewFile/1643/1531

(nedlastet 02.11.17). 